\title{
Object control in Korean: Obligatory vs. non-obligatory control
}

\author{
Maria Polinsky
}

Harvard University

\section{Introduction*}

Object control is a dependency between the object of a matrix clause and the subject of the embedded clause, where the referential properties of the overt controller determine the referential properties of the silent controllee (represented as a gap below), as in (1).

(1) Kim persuaded $\mathrm{Pat}_{i} \quad\left[{ }_{\ldots} i\right.$ to run this race $]$ controller controllee

The degree of referential dependency between the controller and controllee varies from cases where the missing subject of the embedded clause has to be identified with the overt controller in the matrix clause, as in (1), to cases where there can be more than one unique controller, as in (2) and (3), and even further to cases where any controller would do (4):

(2) $\mathrm{Kim}_{\mathrm{i}}$ asked Pat $\mathrm{j}_{\mathrm{j}} \quad\left[{ }_{\ldots}{ }_{i+j}\right.$ to meet in the lobby $]$

(3) $\mathrm{Kim}_{\mathrm{i}}$ asked Pat $\mathrm{j}_{\mathrm{j}} \quad$ [if it was time [ _ _ $i, j, k$ to believe in himself/herself/ themselves/oneself]

(4) $\mathrm{Kim}_{\mathrm{i}}$ wondered [how __ _arb to exonerate oneself]

Different theories of control account for the range of possibilities available in the identification of the antecedent, from unique to arbitrary, by either positing different silent elements in infinitival structures, or by dividing control predicates into different lexical classes. Under the former approach, it is customary to distinguish between obligatory control (OC), as in (1) and nonobligatory control (NOC), as in (4), with various intermediary cases (Chomsky 1981, Koster 1984, Hornstein 2000, 2003, among many others). Each subtype is associated with a different type of empty category: in OC complements it is either PRO or trace of movement, in NOC, it is a null pronominal (pro). Under

* This project was supported in part by NSF grant BCS-0131946. I am grateful to HyonSook Choe, Shin Fukuda, Norbert Hornstein, Peter Jenks, Hakyung Jung, Shin-Sook Kim, Robert Kluender, Nayoung Kwon, Sun-Hee Lee, Phil Monahan, Eric Potsdam, Peter Sells, Barbara Stiebels, Mieko Ueno, and audiences at the JK conference 15, University of Maryland, and Zentrum für allgemeine Sprachwissenschaft in Berlin for helpful discussions of this paper. All errors are my responsibility. 
the latter approach, control predicates can be divided into those that force unique control (as in (1)) versus those that allow a wider range of controllers as in (2) through (4) (Jackendoff \& Culicover 2003). Regardless of a specific account, the difference between $\mathrm{OC}$ and NOC is connected to the difference in complement types and predicate types, with an underlying assumption that the meaning of the matrix predicate should determine the type of control.

In this paper, I examine two object control constructions in Korean which differ only in the surface word order: in one of the constructions, the control complement follows the controller, but in the other, precedes it. I argue that the contrast between these constructions cannot be attributed to scrambling. The difference between these constructions can only be captured if one of them is analyzed as OC, and the other as instantiating NOC. Section 2 presents the relevant constructions and their earlier analyses available in the literature; section 3 presents a detailed discussion of differences between the two object control constructions. My proposal for analyzing these constructions is presented in section 4. Section 5 introduces two outstanding questions related to the proposed structures: the status of scrambling in Korean and the analysis of the inverse control construction. Conclusions and general discussion follow in section 6 .

\section{Object control in Korean}

Object control in Korean involves one of a number of matrix control verbs shown in (5), and a complement clause headed by the complementizer -tolok (see Kim 1978, 1984 for evidence that it is actually a complementizer).

$$
\begin{aligned}
& \text { seltukhata 'persuade', kwonyuhata 'suggest, recommend', kangyohata } \\
& \text { 'force', kwuenhata 'recommend', myenglyenghata 'order', pwuthakhata } \\
& \text { 'ask (as a favor)', yokwuhata 'ask, request', congyonghata } \\
& \text { 'recommend/encourage', cisihata 'order', thailuta 'implore', } \\
& \text { pwuchwukita 'encourage', yochenghata 'entreat' }
\end{aligned}
$$

The construction is illustrated in (6), with the missing argument represented atheoretically as a gap:

$\begin{array}{llll}\text { Chelswu-nun } & \text { Yenghi } \mathrm{i}_{-}-\mathrm{lul} \quad\left[\mathrm{L}_{\mathrm{i}} \quad \begin{array}{l}\text { tomangka-tolok }] \\ \text { run.away-COMP }\end{array}\right. & \begin{array}{l}\text { seltukhayssta } \\ \text { persuaded }\end{array} \\ \text { Chelswu-TOP } & \text { Yenghi-ACC } & \\ \text { 'Chelswu persuaded Yenghi to run away.' }[A C C 1] & \end{array}$

This construction, which I will refer to as ACC1, alternates with the ACC2 construction, illustrated in (7), where the complement clause precedes the accusative DP. 


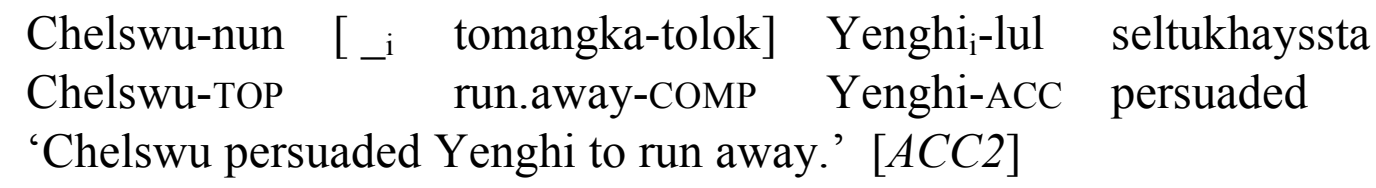

Korean also has an inverse (backward) control construction where the overt controller appears in the embedded clause, and the matrix clause has a silent element, whose surface position is not clear:
a. Chelswu-nun
[Yenghi $\mathrm{i}_{\mathrm{i}}-\mathrm{ka}$
tomangka-tolok]
seltukhayssta
Chelswu-TOP
Yenghi-NOM
persuaded
$\begin{array}{llll}\text { b. Chelswu-nun } & \text { [Yenghi }{ }_{i}-\mathrm{ka} & \text { tomangka-tolok }{ }_{2} \mathrm{i} & \text { seltukhayssta } \\ \text { Chelswu-TOP } & \text { Yenghi-NOM } & \text { run.away-COMP } & \text { persuaded }\end{array}$ 'Chelswu persuaded Yenghi to run away.' [NOM]

This construction, which has received significant attention in the literature (Monahan 2003, 2005, Cormack \& Smith 2004, Choe 2006), will play only a minor role in the discussion here; I will return to it in section 5.2. In addition, Korean has an object control construction with the controller in the dative, rather than accusative case. I will not discuss it in this paper; for an overview of that construction, see Gamerschlag (this volume).

I assume as given, following the analysis in Monahan (2003) and Cormack \& Smith (2002) that both ACC1 and ACC2 are biclausal and that they show evidence of control. The two structures have previously been analyzed as either syntactic control or semantic control. Under both analyses that have been proposed in the literature, $\mathrm{ACC} 1$ and $\mathrm{ACC} 2$ are viewed as derivationally related.

Under the syntactic analysis, which treats control as raising into a thetaposition, the matrix and embedded DP form an A-chain. In both accusative constructions (ACC1, ACC2), the tail of the chain is deleted, instantiating obligatory forward control. (An analysis in terms of PRO could also be pursued, but since recent syntactic work on these Korean constructions has relied on a movement approach, this is what is represented here.)

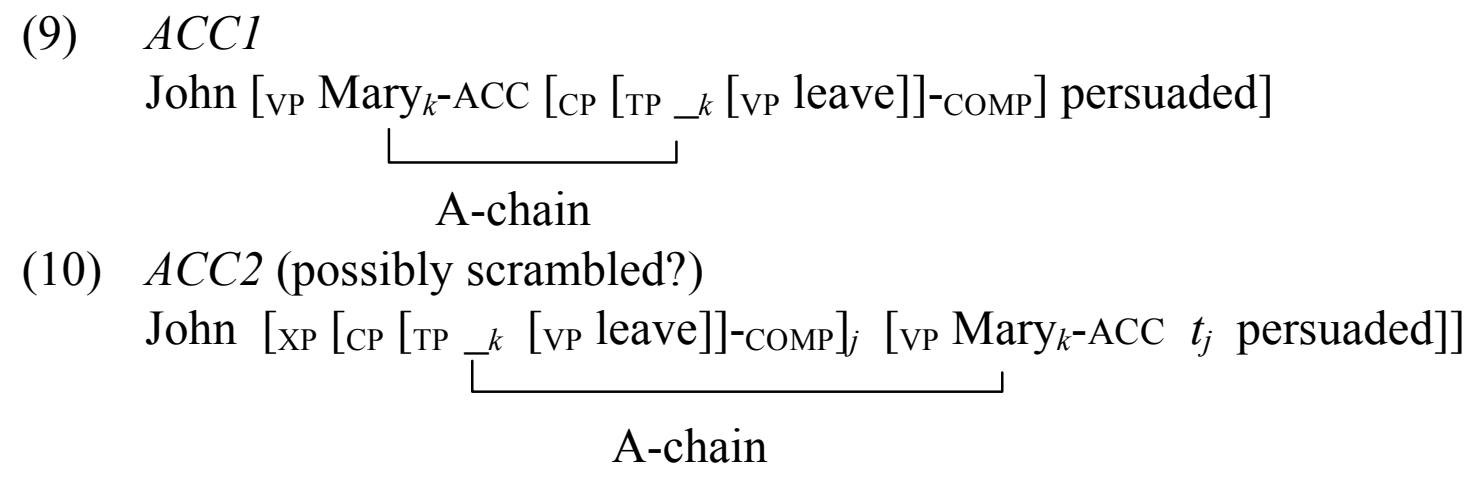

The semantic analysis of control relies on the fact that Korean has extensive subject pro-drop. This analysis assumes that the silent element in all three control constructions is a null pronominal. Then the overt DP is analyzed as 
being co-indexed with a null pronominal, via a meaning postulate (Agent-toAgent). In those instances where coindexation is impossible, the null pronominal is interpreted non-referentially (Cormack \& Smith 2002, 2004; Choe 2006).

According to this analysis, ACC1 is the basic structure, with the accusative DP in the specifier of VP, and the control complement adjoined to V' as shown in (11). The accusative DP c-commands the nominative DP (expressed by a null pronominal) in the embedded clause. The control interpretation is achieved by the meaning postulate which links the agent of the embedded proposition and the persuadee of the matrix (Cormack \& Smith 2004):

(11) John [vp [Mary $\left.{ }_{\mathrm{i}}-\mathrm{ACC}\right]\left[\mathrm{v}^{\prime}\right.$ [ст [тр pro $_{\mathrm{i}}$ leave]-COMP] persuaded]

Korean has object pro-drop, so the object of the matrix clause can be expressed by a null pronominal; the resulting structure, where the null pronominal in the object position is coindexed with the embedded subject, leads to a binding violation:

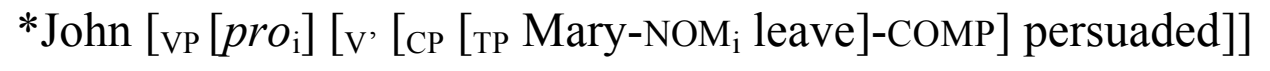

The apparent violation of Condition $\mathrm{C}$ in (12) seems to be remedied by local scrambling (within the verb phrase). Under such scrambling, the control complement appears in the specifier of VP, and the matrix DP adjoins to V':

(13) John [ ${ }_{\mathrm{vP}}\left[{ }_{\mathrm{CP}}\left[\mathrm{TTP}_{\mathrm{i}} \mathrm{DP}_{\mathrm{i}} \text { leave }\right]-\mathrm{COMP}\right]_{\mathrm{k}}\left[\mathrm{vp}_{\mathrm{p}}\left[\mathrm{DP}_{\mathrm{i}}-\mathrm{ACC}\right]\left[\mathrm{v}, \mathrm{t}_{\mathrm{k}}\right.\right.$ persuaded $\left.]\right]$

In this structure, either of the coindexed DPs (the matrix object or the embedded subject) can be expressed by a null pronominal:

(14) John [Vp [Cе [TP pro $_{\mathrm{i}}$ leave $\left.]-\mathrm{COMP}\right]\left[\mathrm{V},\left[\mathrm{DP} \mathrm{i}_{\mathrm{i}}-\mathrm{ACC}\right]\right.$ persuaded $\left.]\right]$

The control interpretation is achieved by the meaning postulate; when a referential antecedent of the null pronoun is not available, pro is interpreted arbitrarily (Choe 2006). To summarize, the existing approaches consider ACC1 and $\mathrm{ACC} 2$ derivationally related, with the assumption that $\mathrm{ACC} 1$ instantiates the base-generated structure, and ACC2 is derived via scrambling. Under the syntactic approach, both constructions are OC, while under the semantic approach both are NOC, thus:

\begin{tabular}{|l|c|c|}
\hline & Syntactic approach & Semantic approach \\
\hline ACC1 & OC & NOC \\
\hline ACC2 & OC & NOC \\
\hline
\end{tabular}

In the next section, I will revisit the relationship between the two constructions arguing that they are not related derivationally, and that they instantiate different types of control. The differences between ACC1 and ACC2 follow without additional stipulations, and the overall contrast between the two constructions 
becomes more reminiscent of the contrasts between obligatory and nonobligatory control in familiar languages.

\section{Differences between ACC1 and ACC 2}

On closer scrutiny, it turns out that the two control constructions, which seem to diverge only in word order, actually differ more profoundly in structural and interpretive properties.

First, ACC1 does not allow an arbitrary antecedent, ${ }^{1}$ whereas ACC2 does:

a. Chelswu-nun emeni-lul [ $\mathrm{ku}$ cha-lul phal-tolok] seltukhayssta Chelswu-TOP mother-ACC that car-ACC sell-COMP persuaded [ACC1]

(i) 'Chelswu persuaded mother to sell the car.'

?/*(ii) 'Chelswu persuaded mother that someone should sell the car.'

b. Chelswu-nun [_ ku cha-lul phal-tolok] emeni-lul seltukhayssta Chelswu-TOP that car- ACC sell-COMP mother-ACC persuaded [ACC2]

(i) 'Chelswu persuaded mother to sell the car.'

(ii) 'Chelswu persuaded mother that someone should sell the car.'

Second, as (16) shows, ACC1 does not allow a non-c-commanding antecedent, whereas ACC2 does (see also Choe 2006, ex. (35)):

(16) a. Chelswu-nun Yenghi-uy emeni-lul [_ ku cha-lul phal-tolok] Chelswu-TOP Yenghi-GEN mother-ACC that car-ACC sell-COMP seltukhayssta persuaded $[A C C 1]$

(i) 'Chelswu persuaded Yenghi's mother to sell the car.'

?/*(ii) 'Chelswu persuaded Yenghi's mother that someone should sell the car.'

*(iii) 'Chelswu persuaded Yenghi's mother that Yenghi should sell the car.'

b. Chelswu-nun [_ ku cha-lul phal-tolok] Yenghi-uy emeni-lul Chelswu-TOP that car- ACC sell-COMP Yenghi-GEN mother-ACC seltukhayssta persuaded $[A C C 2]$

(i) 'Chelswu persuaded Yenghi's mother to sell the car.'

(ii) 'Chelswu persuaded Y.'s mother that someone should sell the car.'

(iii) 'Chelswu persuaded Y.'s mother that Yenghi should sell the car.'

1 As the symbols $* /$ ? on (ii) in (15a) indicate, there is some variation in judgments here. I will return to this issue in section 5 below. 
Next, the two constructions differ as to whether the silent subject in the tolokclause can alternate with an overt pronoun: such an alternation is impossible in ACC1 but is fine in ACC2 (see also Cormack \& Smith 2004, Choe 2006):
a. *Chelswu-nun Yenghi-lul [ku-ka ttena-tolok] seltukhayssta Chelswu-TOP Yenghi-ACC s/he-NOM leave-COMP persuaded [ACC1]
'Chelswu persuaded Yenghi to leave.'
b. Chelswu-nun [ku-ka ttena-tolok] Yenghi-lul seltukhayssta
Chelswu-TOP s/he-NOM leave-COMP Yenghi-ACC persuaded [ACC2]
'Chelswu persuaded Yenghi to leave.'
'Chelswu persuaded Yenghi that someone should leave.'

These differences between $\mathrm{ACC} 1$ and $\mathrm{ACC} 2$ suggest that when it comes to the uniqueness of the antecedent for the missing subject of the tolok-clause, the two constructions have different restrictions. In $\mathrm{ACC} 1$, the requirement seems to be quite stringent: not only does the antecedent of the silent subject have to be unique but it also c-commands the gap. In ACC2, the interpretation of the silent controllee is not limited to the unique controller that follows the tolok-clause. To summarize our results so far, ACC1 and ACC2 differ along the lines of the wellknown differences between obligatory control and non-obligatory control, namely:
properties of OC versus NOC
a. allows arbitary reading (no antecedent)
b. allows a non-c-commanding antecedent
c. paraphrasable with a pronoun

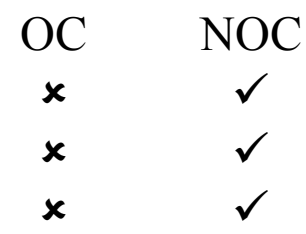

The characteristics of ACC1 correspond to those of OC, while ACC2 matches several criterial properties of NOC. Thus, ACC1 is obligatory control and ACC2 is not.

In addition to the difference in the range of available antecedents and the interpretations that follow from this difference, ACC1 and ACC2 also differ with respect to the interpretation of the controlled event as implicative (ACC1) or not (ACC2). In other words, the use of ACC1 implies that the event described by the embedded clause has to happen (without presupposing it), whereas with $\mathrm{ACC} 2$, the speaker is not committed to the truth of the proposition expressed by the embedded clause. The evidence for this interpretive contrast comes from the fact that ACC1 is infelicitous with the continuation that cancels the event expressed in the embedded clause; for ACC2, such a continuation does not lead to a contradiction: 
(19) a. Chelswu-ka Yenghi-lul hakkyo-lul ttena-tolok seltukhayssta. Chelswu-NOM Yenghi-ACC school-ACC leave-COMP persuaded \#Kulenta pro/Yenghi-nun hakkyo-lul ttena-ci Anh-ass-ta but pro/Yenghi-TOP school-ACC leave-INF NEG-PAST-DECL [ACC1]

'Chelswu persuaded Yenghi ${ }_{\mathrm{k}}$ to quit school, \#but even so $\mathrm{she}_{\mathrm{k}} /$ Yenghi did not.' (contradiction)

b. Chelswu-ka hakkyo-lul ttena-tolok Yenghi-lul seltukhayssta. Chelswu-NOM school-ACC leave-COMP Yenghi-ACC persuaded Kulenta pro/Yenghi-nun hakkyo-lul ttena-ci anh-ass-ta But pro/Yenghi-TOP school-ACC leave-NEG NEG-PAST-DECL [ACC2]

'Chelswu persuaded Yenghi ${ }_{\mathrm{k}}$ to quit school, but even so $\mathrm{she}_{\mathrm{k}} /$ Yenghi did not.' (no contradiction)

The contrast between $\mathrm{ACC} 1$ and $\mathrm{ACC} 2$ is reminiscent of the contrast between implicative and non-implicative control in English, for example, as in (20), which corresponds to the Korean ACC1, and (21), whose interpretation corresponds to that of $\mathrm{ACC} 2 .^{2}$ In English, the difference in implicativeness correlates with the use of the infinitival vs. finite complement (cf. Jackendoff \& Culicover 2003), whereas in Korean it seems to be simply linked to difference in surface word order. ${ }^{3}$

(20) John persuaded Mary to buy a BMW, ??/*but even so she didn't.

(21) John persuaded Mary that she should buy a BMW but even so she didn't.

All said it seems that the difference between ACC1 and ACC2 goes deeper than just a simple difference in scrambling. While scrambling may affect c-command relations (Saito 2003, Tsoulas 2004, Ko 2005, Choe 2006) ${ }^{4}$ and brings about some differences in topic interpretation or aboutness (Choi 2001), it is not known to have profound consequences for the interpretation of the null element in a control complement or to cause differences in implicativeness. Thus it seems possible that both constructions are independent and base-generated rather than one being derived from the other.

A possible counter-argument against such an approach comes from the differences between ACC1 and ACC2 with respect to extraction. In ACC1, the

2 I would like to thank Ray Jackendoff for a helpful discussion of this contrast in English.

3 It is striking that both English and Korean show a correlation between non-obligatory control and non-implicative interpretation. Intuitively, such a correlation does not seem accidental, but more work is needed to motivate it.

4 In Korean, scrambling has been shown to have an effect on condition A binding (Choi 2001) but not on condition C binding (Johnston \& Park 2001). 
tolok-clause is transparent and can be extracted out of the complement clause in (22b), but in ACC2, the extraction out of that clause is marginal at best (23b).

(22) a. Chelswu-ka Yenghi-lul [ku chayk-ul ilk-tolok] seltukhayssta. Chelswu-NOM Yenghi-ACC this book-ACC read-COMP persuaded 'Chelswu persuaded Yenghi to read this book.' [ACC1]

b. ku chayk-ul $\mathrm{i}_{\mathrm{i}}$, Chelswu-ka Yenghi-lul [ $\mathrm{t}_{\mathrm{i}}$ ilk-tolok] seltukhayssta this book-ACC Chelswu-NOM Yenghi-ACC read-COMP persuaded 'This book, Chelswu persuaded Yenghi to read.'

(23) a. Chelswu-ka [ku chayk-ul ilk-tolok] Yenghi-lul seltukhayssta. Chelswu-NOM this book-ACC read-COMP Yenghi-ACC persuaded 'Chelswu persuaded Yenghi to read this book.' [ACC2]

b. ??/* $\mathrm{ku}$ chayk-ul $\mathrm{i}_{\mathrm{i}}$ Chelswu-ka [ $\mathrm{t}_{\mathrm{i}}$ ilk-tolok $]$ Yenghi-lul this book-ACC Chelswu-NOM read-COMP Yenghi-ACC seltukhayssta persuaded 'This book, Chelswu persuaded Yenghi to read.'

This difference between ACC1 and ACC2 (22b) and (23b) seems consistent with the idea that ACC2 is derived from ACC1 by scrambling. Scrambling creates an island for further extraction (Saito 2003, Ko 2005, and many others), which should account for (23b). However, the ungrammaticality of (23b) can be accounted for independent of scrambling, under the structure which will be proposed in the next section. So at least for now, I suggest maintaining the idea that $\mathrm{ACC} 1$ and $\mathrm{ACC} 2$ are not related derivationally and instantiate different flavors of control.

\section{Structure of ACC1 and ACC2}

\section{1. $\mathrm{ACC1}$}

We have established that the structure in ACC1 instantiates obligatory control. The matrix verb (for example, 'persuade') takes two complements, the accusative DP (controller) and the complement clause (-tolok). These two internal arguments (the name of the persuadee and the embedded complement) are in the specifier and complement positions in the VP, which means that the accusative DP c-commands the complement clause, thus (English words are used to illustrate the Korean structure; only the necessary structural pieces are shown):

Chelswu-NOM [vP Yenghi $\mathrm{i}_{\mathrm{i}} \mathrm{ACC}\left[\mathrm{v},\left[\mathrm{CP}\left[\mathrm{TP} \_\mathrm{i}\right.\right.\right.$ leave $\left.] \mathrm{C}^{\circ}\right]$ [v persuade $\left.]\right]$ 
The missing subject in the embedded clause can be interpreted in two possible ways: as containing a special null category, PRO, or as involving a thematic chain in which the tail is deleted, thus:

$\begin{array}{lllll}\text { Chelswu-ka } & \text { Yenghi-lul } & \text { [PRO } & \text { ttena-tolok }] & \text { seltukhayssta } \\ \text { Chelswu-NOM } & \text { Yenghi-ACC } & \text { leave-COMP } & \text { persuaded }\end{array}$

a. Chelswu-ka Yenghi-lul [Yenghi ka ttena-tolok] seltukhayssta Chelswu-NOM Yenghi-ACC leave-COMP persuaded

b. Chelswu-NOM [vpYenghi-ACC [ст [тP Yenghi-NOM [vp go]] C] persuade]

To outline the movement analysis, as in (26), the DP Yenghi is merged in the embedded spec, $\mathrm{T}^{\circ}$. There, it satisfies the thematic requirements of the embedded verb leave and the $\varphi$-features of embedded $\mathrm{T}^{\circ}$. It then merges into matrix object position, satisfying the thematic requirements of the matrix verb, which assigns it accusative case. The head of the chain formed by the matrix object and the subject of the embedded clause is pronounced, while the other copy is deleted.

For general details of the movement analysis of control, see Hornstein (2003), Monahan (2005). For the discussion of factors that may determine the spell-out of the tail rather than head of the movement chain, see Polinsky \& Potsdam (2006), Potsdam (2006). Lastly, for comparison of the PRO-based and movement analysis, see Landau (2003, 2004, 2006), Hornstein \& Boeckx (2004), Boeckx \& Hornstein (2006), Polinsky \& Potsdam (2006).

\section{2. $\mathrm{ACC} 2$}

Recall that the ACC2 construction instantiates non-obligatory control, which means that the missing subject inside the embedded clause is a null pronominal. The null pronominal can alternate with an overt one (see (17b) above). Crucially, the subject of the tolok-clause is not c-commanded by the accusative controller in the matrix clause, and the dependency between the accusative controller and the silent controllee is referential, rather than syntactic. The two expressions are thus related by simple co-indexation. They do not have to have identical denotations, which is shown by examples such as (27) and (28), where the referent of the embedded subject and the referent of the matrix object are simply associated pragmatically.
cokyo-ka [haksayng-tul-i te umak swuep-ul tut-tolok] teacher's aide-NOM student-PL-NOM more music lesson-ACC take-COMP hakpwumo-tul-ul seltukhayssta

parent-PL-ACC persuaded [ACC2]

'The teacher's aide persuaded the parents of the students that their children should take more music lessons.' 


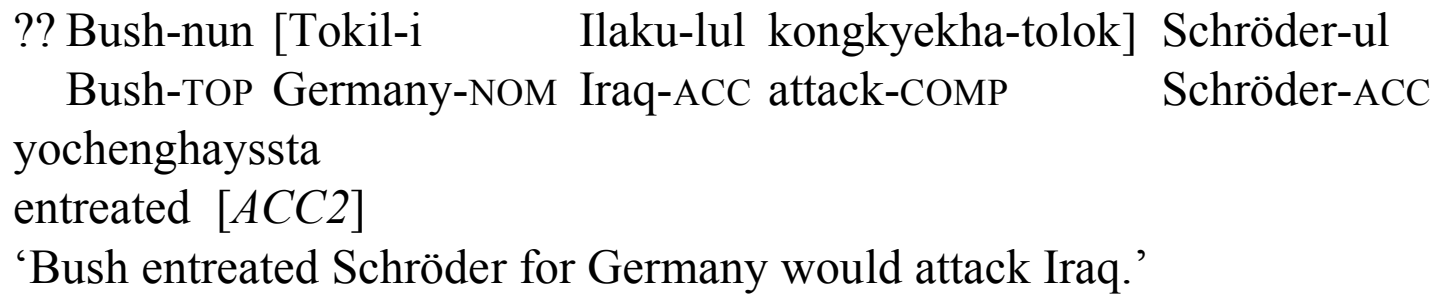

Recall also that even such pragmatic association is not required, and in the absence of other cues, an arbitrary reading of the null pronominal is equally possible (cf. (15b) above).

Since there is no c-command between the controller and controllee, variable binding should be impossible. While reflexive data are unclear (thus raising more general questions about the nature of anaphors in Korean), indefinite expressions (29) and negative polarity items (30) in ACC2 confirm this prediction and do not participate in co-indexation (see also Choe 2006, ex. (26), (36), and (40)):
Chelswu-ka
$\left[\right.$ pro $_{\mathrm{i}}$ ttena-tolok]
nwukwu $\mathrm{k}-1 \mathrm{ul}$
seltukhayss-nayo?
Chelswu-NOM
leave-COMP who-ACC
persuaded-INTERR

'Whom ${ }_{\mathrm{k}}$ did Chelswu persuade that someone $\mathrm{i}_{\mathrm{i}}$ should leave?'
(30) Chelswu-ka $\left[\right.$ pro $_{i}$ ttena-tolok $]$ amwuto $_{k}$ seltukha-ci anh-ass-ta Chelswu-NOM leave-COMP anyone persuade-INF NEG-PAST-DEC 'Chelswu did not persuade anyone $\mathrm{k}_{\mathrm{k}}$ that someone $\mathrm{i}_{\mathrm{i}}$ should leave.'

This is in contrast to the variable binding freely available in ACC1. Compare (29) with (31); in (29), the variable binding interpretation is not allowed, whereas in (31) it is available, which follows from the c-command relation between the matrix object and the embedded subject:
(31) Chelswu-ka nwukwu $\mathrm{i}_{\mathrm{i}}-\mathrm{lul} \quad \mathrm{L}_{\mathrm{i}}$ ttena-tolok] seltukhayss-nayo? Chelswu-NOM who-ACC leave-COMP persuaded-INTERR 'Whom did Chelswu persuade to leave?'

Similarly, compare (30) with (32), in which variable binding is available as it is allowed structurally:
Chelswu-ka
amwuto $_{i}\left[{ }_{i}\right.$ ttena-tolok]
seltukha-ci
anh-ass-ta
Chelswu-NOM leave-COMP
'Chelswu did not persuade anyone to leave.'

All these data further support the difference between ACC1 and ACC2 and confirm the pronominal nature of the empty element in ACC2.

Assuming that there is no c-command between the accusative controller and tolok-clause, what is the structural position of that clause?

To answer this question, let's start with the argument structure of 'persuade' and other verbs listed in (5) above. They all appear to be standard three-place 
predicates, which take an agent, a theme (persuadee), and a propositional object, corresponding to the intended event. In the standard control structure (ACC1), this propositional object is expressed by the tolok-clause. For ACC2, I propose that this object is an implicit argument, semantically bound by the overt tolokclause, which appears in the adjunct position in the verb phrase. The verb thus still has a propositional object as its internal argument, remaining a three-place predicate, but there is an additional adjunct higher in the verb phrase filled with the tolok-clause. The proposed structure of ACC2 is as follows:

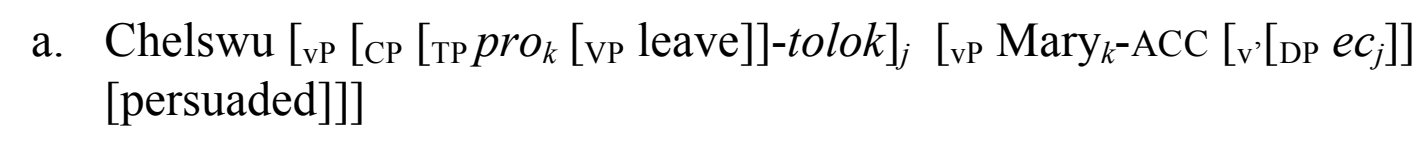

b.

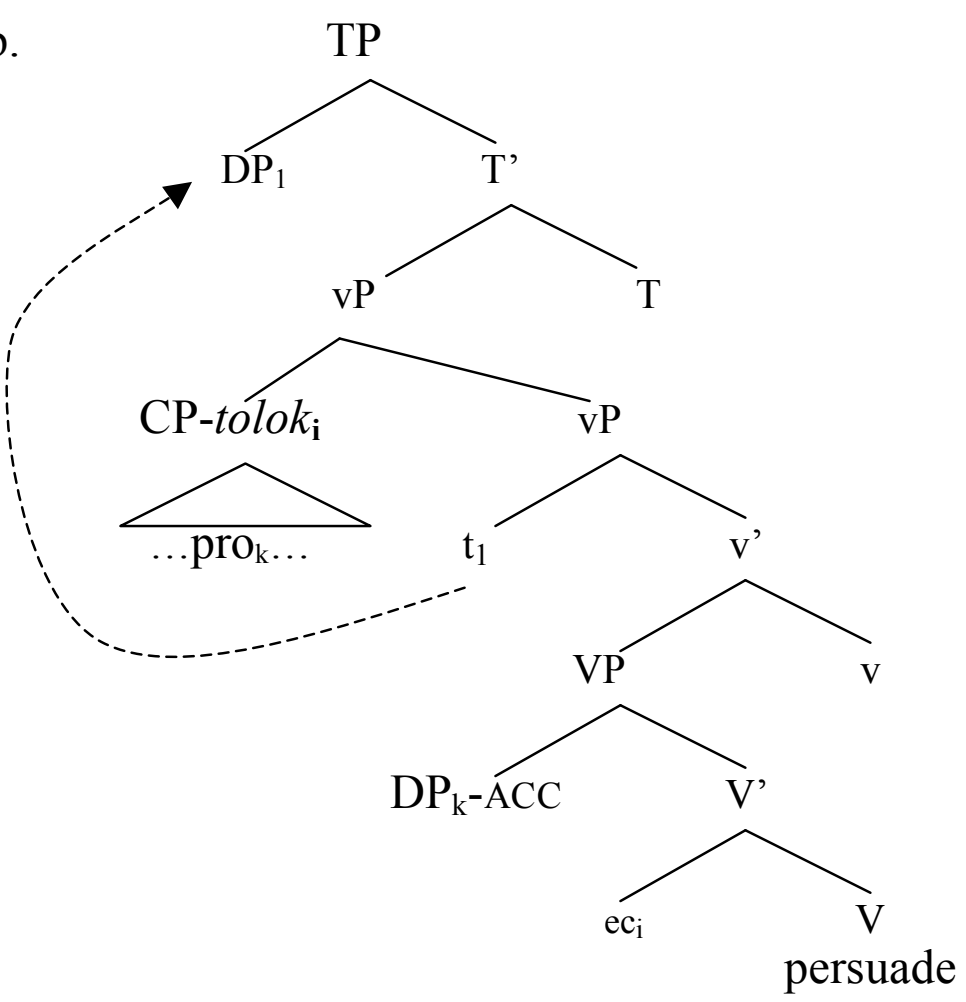

The evidence for this structure involves several analytical components. First, evidence for the implicit argument position is desirable. Second, we need to demonstrate that the tolok-clause is indeed an adjunct, situated at the left periphery of the verb phrase.

Starting with the implicit argument, one could expect that such an argument could alternate with an overt object, for example with some abstract noun ('idea', 'proposal') or a pronoun, something like the anticipatory it in English. However, due to the pervasive nature of Korean object pro-drop (about $50 \%$ of objects are null, cf. Kim 2000), even referential arguments are often awkward when overtly expressed, let alone abstract, propositional entities. Note that even in English, where there is no pro-drop, anticipatory it in the position of a propositional object is rather awkward: 
... so well convinced him of $i t$ that he has become quite anxious to have you apply for the chair

(jhmas.oxfordjournals.org/cgi/reprint/XXIV/1/44.pdf)

Although a pronominal or an abstract DP seems impossible, the implicit argument position can be filled with a clausal complement, co-occuring with the higher tolok-clause: ${ }^{5}$

(35) a. Chelswu-nun $\left[\right.$ pro $_{i}$ Yenghi-lul manna-tolok $]$ Minswu $_{i}-1 u l$ Chelwsu-TOP Yenghi-ACC Meet-COMP Minswu-ACC

[_i Seoul-lo ka-key] seltukhayssta

Seoul-to go-COMP persuaded

'Chelswu persuaded Minswu to go to Seoul to meet Yenghi.'

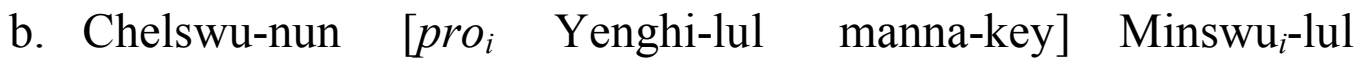

Chelwsu-TOP Yenghi-ACC meet-COMP Minswu-ACC

[_i $\quad$ Seoul-lo ka-tolok] seltukhayssta

Seoul-to go-COMP persuaded

'Chelswu persuaded Minswu to go to Seoul to meet Yenghi.'

Speakers prefer for the two embedded clauses to have to have different complementizers, as in (35), but the following example, with both clauses headed by tolok is acceptable to some (the variation in judgments seems to hold across speakers; individual speakers are consistent in either accepting or rejecting double -tolok sentences):

$$
\begin{aligned}
& \% \text { Chelswu-nun }\left[\mathrm{pro}_{\mathrm{i}}\right. \text { amwu kekceng-epsi sal swuiss-tolok] } \\
& \text { Chelwsu-TOP any worry-without live be.able-COMP } \\
& \text { Minswu }_{\mathrm{i}}-\text { lul [_i Seoul-ul ttena-tolok] seltukhayssta } \\
& \text { Minswu-ACC Seoul-ACC go-COMP persuaded } \\
& \text { 'Chelswu persuaded Minswu to leave Seoul so that he (Minswu) would } \\
& \text { live without worry.' }
\end{aligned}
$$

Turning now to the position of the tolok-clause in ACC2, evidence that it is at the left edge of the verb phrase comes from adverbial placement. Korean has several adverbials that are ambiguous between high and low adverbs (Sohn 2001; Ko 2005). For example, the adverbial palo has the meaning 'directly; true, indeed' as an IP-adverb, and the meaning 'immediately' as a VP-adverb (Sohn 2001:212). Consider the following sentence, where palo is placed to the left of the tolok-clause and where it can only have the VP-adverb interpretation:

5 I am leaving open the question about the category of the empty element in the second control clause. 
Chelswu-ka palo [onil__ _i hakkyo-lul ttena-tolok] Yenghi-lul Chelwsu-NOM ADV tomorrow school-ACC leave-COMP Yenghi-ACC selthuhaessta

persuaded

'Chelswu immediately persuaded Yenghi to quit school tomorrow.'

NOT: 'Chelswu indeed/truly persuaded Yenghi to quit school tomorrow.'

The VP-adverb interpretation of the adverbial which precedes the tolok-clause indicates that this clause is inside the verb phrase, adjoined to the vP.

The argument in support of the adjunct status of the preposed tolok-clause in ACC2 comes from extraction restrictions. ${ }^{6}$ If the preposed tolok-clause is an adjunct, it should be an island for extractions. Empirical facts show that it is. Recall that scrambling or topicalization out of the tolok-clause in ACC2 was ungrammatical:

$$
\begin{aligned}
& ? ? /{ }^{*} \mathrm{ku} \quad \text { chayk-ul } \mathrm{i}_{\mathrm{i}}, \quad \text { Chelswu-ka } \quad\left[\mathrm{t}_{\mathrm{i}} \text { ilk-tolok }\right] \text { Yenghi-lul } \\
& \text { this book-ACC Chelswu-NOM read-COMP Yenghi-ACC } \\
& \text { seltukhayssta } \\
& \text { persuaded } \\
& \text { 'This book, Chelswu persuaded Yenghi to read.' (=(23b)) }
\end{aligned}
$$

If the analysis proposed here is on the right track, then the islandhood of tolokclauses in ACC2 follows from their adjunct status, not from scrambling. At this point, one could imagine that the two explanations are equally valid; however, there is additional evidence suggesting that the adjunct island explanation is the correct one.

This evidence comes from constraints on scrambling over an already scrambled element. In Korean, scrambling over a scrambled constituent is ungrammatical, which is illustrated by the following examples. In (39b), the word 'book' has been scrambled out of the embedded clause, which is grammatical, but scrambling of the remnant embedded clause over 'book' is ungrammatical $(39 \mathrm{c}):^{7}$

6 Assuming the optionality of adjuncts, one can also expect the tolok-clause to be omitted, with the verb taking only one overt object, as in (i). Of course, in such a case it is hard to tell if this surface structure reflects ACC1 or ACC2.

(i) Chelswu-nun Minswu-lul ec seltukhayssta

Chelswu-TOP Minswu-ACC Persuaded

'Chelswu convinced Minswu (of something).'

7 I am grateful to Shin-Sook Kim for calling my attention to this paradigm in scrambling. 
a. Chelswu-ka [Yenghi-ka ku chayk-ul ilkessta-ko]

Chelswu-NOM Yenghi-NOM that book-ACC read-that sayngkakha-n-ta

think-PRES-DEC

'Chelswu thinks that Yenghi read that book.'

b. $\mathrm{ku}$ chayk-ul $\mathrm{i}_{\mathrm{i}}$ Chelswu-ka [Yenghi-ka $t_{\mathrm{i}}$ ilkessta-ko]

that book-ACC Chelswu-NOM Yenghi-NOM read-that

sayngkakha-n-ta

think-PRES-DEC

'That book, Chelswu thinks that Yenghi read.'

c. * [Yenghi-ka $t_{\mathrm{i}}$ ilkessta-ko $]_{\mathrm{k}} \quad \mathrm{ku}$ chayk-ul $\mathrm{i}_{\mathrm{i}}$ Chelswu-ka $t_{\mathrm{k}}$ Yenghi-NOM read-that that book-ACC Chelswu-NOM sayngkakha-n-ta

think-PRES-DEC

('That Yenghi read it, that book, Chelswu thinks.')

The paradigm in (39) allows us to establish the baseline generalization: scrambling over a scrambled constituent in Korean is ungrammatical. If the tolokclause in ACC2 is in its surface position due to scrambling, then scrambling over it should also be ungrammatical. However, this prediction is not borne out: in (40b), a prepositional phrase is scrambled over the tolok-clause, but the sentence remains grammatical.
a. Chelswu-nun
$\left[\right.$ pro $_{i}$
hakkyo-ey
ka-tolok]
Yenghi-lul $1_{i}$
Chelswu-TOP school-to
go-COMP
Yenghi-ACC
[PP kunyecasin ${ }_{\mathrm{i}}$-uy yuik-ul
wihay] seltukhayssta
herself-GEN
benefit-ACC for
persuaded

'Chelswu persuaded Yenghi to go to school for her own benefit.'

(Monahan 2005, ex. (39))

b. Chelswu-nun [PP kunyecasin ${ }_{i}$-uy yuik-ul wihay $]_{j}$

Chelswu-TOP herself-GEN benefit-ACC for

$\left[\right.$ pro $_{i}$ hakkyo-ey ka-tolok] Yenghi-lul ${ }_{\mathrm{i}} t_{\mathrm{j}}$ seltukhayssta

school-to go-COMP Yenghi-ACC persuaded

'Chelswu, for her own benefit, persuaded Yenghi to go to school.'

Equally grammatical is (41b), where the low adverbial mwulyeyhakey 'in a rude manner' is scrambled over the tolok-clause: ${ }^{8}$

8 Adverbs such as 'rudely' are ambiguous between high and low adverbials (Ko 2005). However, Ko (2005: 59-60) proposes a useful diagnostic for disambiguating the two readings in Korean: when an adverb such as 'rudely' appears between the subject and the floated quantifier it is interpreted as a high adverb, but when it follows the quantifier as in (41b) it is interpreted low. Thus in (41b) the adverb starts out in the vP and scrambles out. 
$(41)$

$\begin{array}{lllll}\text { a. haksayng-tul-i } & \text { sey-myeng } & \text { ecey } & \text { [maykcwu-lul } \\ \text { student-PL-NOM } & \text { 3-CL } & \text { yesterday beer-ACC } \\ \text { masi-tolok] } & \mathrm{ku} & \text { ai-lul } & \text { mwulyeyhakey } & \text { cisihayssta } \\ \text { drink-COMP that } & \text { child-ACC } & \text { rudely } & \text { ordered }\end{array}$

'Yesterday three students rudely ordered the child to drink beer.'

b. haksayng-tul-i sey-myeng mwulyeyhakeyi ecey student-PL-NOM 3-CL rudely yesterday

[maykcwu-lul masi-tolok] $\mathrm{ku}$ ai-lul ti beer-ACC drink-COMP that child-ACC ordered

'Yesterday three students rudely ordered the child to drink beer.'

The comparison between (39) on the one hand and (40) or (41) on the other is not ideal, because the examples in (39) involve cross-clausal scrambling, whereas (40) and (41) involve clause-internal scrambling. Therefore I would like to offer this evidence as suggestive but not definitive.

Additional arguments in favor of the adjunct analysis come from processing (Kwon \& Polinsky 2006). In general, scrambling is known to incur an additional processing cost; this has been amply demonstrated for scrambled sentences in Japanese (Mazuka et al. 2002; Ueno \& Kluender 2003; Miyamoto and Takahashi 2002), and for scrambling in Korean (Kwon et al. 2007). However, the two structures discussed here do not differ in terms of reading time (Kwon \& Polinsky 2006), and in fact, the reading time for ACC2 is even slightly faster, as shown in the reading time graph below:

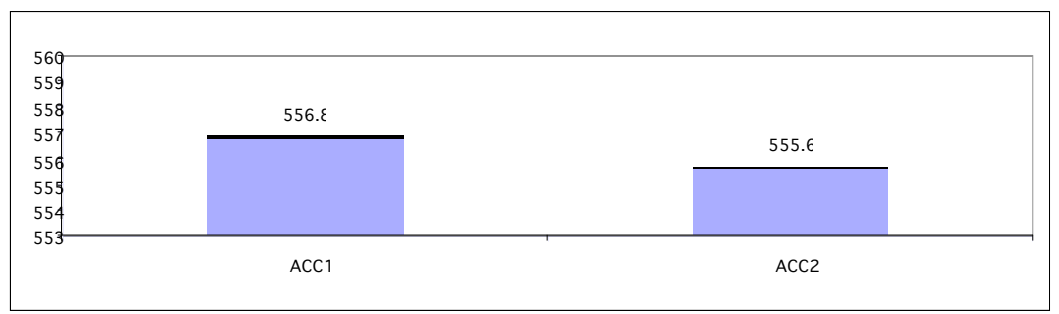

Figure 1 Reading time results (Kwon \& Polinsky 2006)

If scrambling were implicated in ACC2, we would expect it to cause some slowdown in reading, which does not happen. The processing profile shown in Figure 1 is yet another indication that ACC2 is not due to scrambling.

In sum, the evidence for structural differences between ACC1 and ACC2 is quite strong. The controller-controllee relationship in ACC2 is determined on semantic or pragmatic, rather than syntactic, grounds. The referential dependency in ACC2 accounts for the fact that the null pronominal in the tolok-clause can alternate with an overt pronoun (42), and an overt DP whose referent is only relationally associated with the referent of the persuadee, as in (43): 
(42) Chelswu-nun [kunye-ka ttena-tolok] Yenghi-lul seltukhayssta Chelswu-TOP she-NOM leave-COMP Yenghi-ACC persuaded 'Chelswu persuaded Yenghi to leave.' $(=(17 b))$ [3SG coindexed with Yenghi]

cokyo-ka [haksayng-tul-i te umak swuep-ul tut-tolok] teacher's aide-NOM student-PL-NOM more music lesson-ACC take-COMP hakpwumo-tul-ul seltukhayssta parent-PL-ACC persuaded 'The teacher's aide persuaded the students' parents that their children should take more music lessons.' [children coindexed with parents]

\section{Outstanding questions}

\subsection{Where is scrambling?}

Assuming that the two object control constructions in Korean are not derivationally related and are in fact quite different, they may both still be structurally ambiguous, due to scrambling. Scrambling of two internal arguments is possible in Korean (Park \& Whitman 2003, Maling \& Kim 1992, Sells 2005, Baek \& Lee 2004, and others), so it is feasible that each of the surface constructions, ACC1 and ACC2, actually masks two possibilities, thus (using English words with Korean word order):

a. ACC1, direct order

Chelwsu Yenghi $\mathrm{i}_{\mathrm{i}}$-ACC $\left[\mathrm{PRO} / \mathrm{t}_{\mathrm{i}}\right.$ go-COMP $]$ persuaded

b. ACC1, scrambled

Chelwsu $\left[\mathrm{PRO} / \mathrm{t}_{\mathrm{i}} \text { go-COMP }\right]_{\mathrm{k}}$ Yenghi $\mathrm{i}_{\mathrm{i}}$-ACC $\mathrm{t}_{\mathrm{k}}$ persuaded

a. ACC2, direct order

Chelwsu $\left[\text { pro }_{\mathrm{i}} \text { go-COMP }\right]_{\mathrm{j}}$ Yenghi $\mathrm{i}_{\mathrm{i}}-\mathrm{ACC} \mathrm{ec}_{\mathrm{j}}$ persuaded

b. ACC2, scrambled

Chelwsu Yenghi ${ }_{i}$-ACC $\left[\right.$ pro $_{\mathrm{i}}$ go-COMP] $\mathrm{t}_{\mathrm{i}} e c_{\mathrm{j}}$ persuaded

If the two constructions are structurally ambiguous, then ACC1 could actually mask ACC2 (cf. (44b)), and ACC2 could conceal ACC1 (cf. (45b)).

The structure in $(44 \mathrm{~b})$ is untenable on several theory-internal and empirical grounds. Under a PRO-based analysis of control, it is ruled out because of the disruption of c-command between PRO and its antecedent. Adopting a controlas-movement analysis, Monahan (2005) and Kwon \& Polinsky (2006) argue against the scrambling analysis of ACC1, such as that shown in (44b). The main arguments have to do with variable binding (see above) and quantifier float (Monahan 2005). In addition, under a movement analysis of control, the derivation of (44b) involves scrambling (remnant movement) over a moved constitu- 
ent: first the controller has to move, and then the rest of the tolok-clause moves over it to the left. We have seen that such movement is impossible in Korean (see (39c) above), which suggests that ACC1 does not undergo scrambling. Thus, the derivation in (46a) is impossible. However, sentences with the surface order as in (46a) are grammatical, which suggests that they have a different structure, the one shown in (46b).
a. * Chelswu-nun Chelswu-TOP $\left[\begin{array}{lllll}t_{\mathrm{i}} & \text { ka-tolok } \\ \mathrm{k}_{\mathrm{k}} & \begin{array}{l}\text { Yenghi-lul } \\ \text { go-COMP }\end{array} & t_{\mathrm{k}} & \begin{array}{l}\text { seltukhayssta } \\ \text { Yenghi-ACC }\end{array} & \text { persuaded }\end{array}\right.$
b. Chelswu-nun $\left[\text { pro }_{i} \text { ka-tolok }\right]_{\mathrm{k}}$ Yenghi-lul $\mathrm{i}_{\mathrm{i}} \mathrm{ec}_{\mathrm{k}}$ seltukhayssta 'Chelswu persuaded Yenghi to go.'

That (46a) is untenable meshes well with some additional empirical observations: ACC1 is normally judged as unambiguous, and only some speakers show mild ambiguity, reflected in the judgments in (15a) above - note the graded judgments on (ii) there. The next step in understanding such graded judgments should involve a psycholinguistically designed judgment of a larger number of ACC1 examples to evaluate off-line judgments; such a judgment task is currently under development.

Let us now turn to ACC2 and the scrambled representation in (45b). The main argument against this representation comes from island effects. If a subset of ACC 1 constructions were due to scrambling, the tolok-clause in those scrambled structures should remain an island for extractions, so we should expect something like (47a) to be ungrammatical because it would have the structure in (47b) and would involve scrambling out of an adjunct island as well as scrambling over a scrambled constituent ('Yenghi'):
a. ku chayk-ul ${ }_{i}$, Chelswu-ka Yenghi-lul [ $\mathrm{t}_{\mathrm{i}}$ ilk-tolok $]$ this book-ACC Chelswu-NOM Yenghi-ACC read-COMP seltukhayssta
persuaded
'This book, Chelswu persuaded Yenghi to read.' $(=(22 b))$

b. this book $\mathrm{k}_{\mathrm{i}}$ Chelswu-NOM Yenghi $\mathrm{k}_{\mathrm{k}}$-ACC $\left[\text { CP }_{\mathrm{i}} \mathrm{t}_{\mathrm{i}} \text { read-COMP }\right]_{\mathrm{j}} \mathrm{t}_{\mathrm{k}} \quad e c_{\mathrm{j}}$ persuaded

However, (47a) is well-formed, which argues against the structural ambiguity in ACC2 offered in (45).

Taken as a whole, these results cast further doubt on derivational accounts of scrambling. On a more general level, many arguments in favor of scrambling can be shown to be empirically flawed or inconclusive (Fanselow 2001). Theoretically, the concept of A-scrambling conflicts with a number of accepted minimalist assumptions, and base-generation of alternative orders may be a bet- 
ter solution (Fanselow 2001). The data presented here add further empirical support to such a proposal.

\subsection{Status of the nominative construction}

Throughout this paper, I have avoided the discussion of the nominative or inverse control construction, in which the overt controller in the tolok-clause is coindexed with a silent controllee in the matrix clause (for evidence in support of the silent controllee, see Monahan 2003, Cormack \& Smith 2004, Choe 2006):

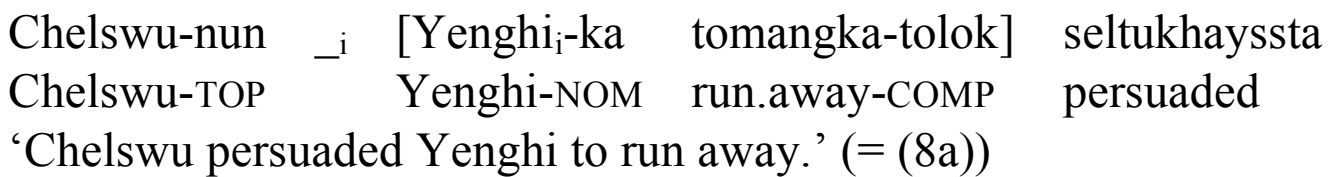

This construction is compatible with both ACC1 and ACC2. If it is related to obligatory control (ACC1), then it should be analyzed as backward control, with the controller and controller related by movement, as proposed in Monahan (2005) and Kwon \& Polinsky (2006). ${ }^{9}$ The difference between this construction and ACC1 then has to do with pronunciation of the tail versus the head of the movement chain.

Because Korean has extensive subject pro-drop, the construction illustrated in (48) is also compatible with non-obligatory control, hence, it could be a variant of ACC2. Under the NOC analysis, the only difference between this construction and $\mathrm{ACC} 2$ lies in the position of the null pronominal. If the null pronominal is in the subject position of the tolok-clause, the result is ACC2, if it is in the object position of the matrix clause, the result is NOM:
a. Chelswu-nun $\left[\mathrm{vp}_{\mathrm{P}}\left[\mathrm{pro}_{\mathrm{i}} \text { tomangka-tolok }\right]_{\mathrm{k}} \quad \mathrm{VvP}_{\mathrm{v}}\right.$ Yenghi $\mathrm{i}_{\mathrm{i}}-\mathrm{lul}$ Chelswu-TOP run.away-COMP Yenghi-ACC
[v, $e c_{\mathrm{k}} \quad$ seltukhayssta] $]$ persuaded
[ACC2]

b. Chelswu-nun ${ }_{\mathrm{vp}} \quad\left[\text { Yenghi }_{\mathrm{i}}-\mathrm{ka} \text { tomangka-tolok }\right]_{\mathrm{k}} \quad$ [vp $_{\text {pro }}$ Chelswu-TOP Yenghi-NOM run.away-COMP

[v, $e c_{\mathrm{k}} \quad$ seltukhayssta]] persuaded [NOM]

'Chelswu persuaded Yenghi to run away.'

Speakers seem to vary with respect to the uniqueness of the antecedent in the controller-controllee relationship in NOM. While preliminary data seem to favor the OC interpretation of NOM, hence the control-as-movement analysis, there is

9 See Polinsky \& Potsdam $(2002,2006)$ and Monahan (2003) for arguments as to why PRO-based analysis of backward control is untenable. 
also serious variation in judgments (see especially Choe 2006), which needs to be investigated further.

\section{Conclusions}

In this paper, I have examined two Korean object control constructions with the complementizer -tolok: where the overt accusative controller in the matrix clause either precedes or follows the embedded clause (ACC1, ACC2). I have argued that these two constructions differ in more than just surface word order of the internal objects. ACC1 instantiates obligatory control (OC) and can be accounted for under either a PRO-based analysis or a movement analysis (which is preferable for independent reasons not discussed in this paper). ACC2 shows non-obligatory control (NOC), and is best accounted for under an analysis which posits a null pronominal inside the control clause, coindexed with an overt accusative DP in the matrix clause. The controller-controllee relationship in ACC2 is based on a referential, rather than a syntactic, dependency. The differentiation of the two constructions as obligatory $v s$. non-obligatory control is supported by structural considerations as well as some processing evidence.

It is intriguing that the difference between OC and NOC in Korean object control is manifested as a word order difference. In more familiar languages, such a difference is typically associated with the difference in the type of control complement - for example, the difference between an infinitival clause and a finite clause in English (Jackendoff \& Culicover 2003), or the difference in lexical predicates. The availability of surface word order as the sole surface feature differentiating $\mathrm{OC}$ and NOC indicates that the range of morphosyntactic options available for expressing this contrast is broader than we think. It would be informative to understand what in general is possible within that range and what other features of a given language correlate with the use of a particular morphosyntactic option separating OC and NOC.

The differential analysis of the two control constructions proposed here brings together insights from work on semantic control in Korean (Cormack \& Smith 2002, 2004; Choe 2006) and syntactic analysis proposed by Monahan $(2003,2005)$. The semantic analysis correctly captures the non-obligatory control cases (ACC2), while the syntactic analysis is more appropriate for obligatory control because it does not need additional stipulations to handle active/passive synonymy (Monahan 2005, Kwon \& Polinsky 2006) or variable binding. 


\section{References}

Baek, J. Y.-K. \& J.-M. Lee (2004). Double object constructions in Korean: Asymmetry between theme and goal. Ohak Yon'gu/Language Research 40, 669-679.

Boeckx, C. \& N. Hornstein (2006). The virtues of control as movement. Syntax 9, 118-130.

Choe, H.-S. (2006). On (backward) object control in Korean. Harvard Studies on Korean Linguistics XI. Kyunggi: Hanshin Pub, 373-386.

Choi, H.-W. (2001). Binding and discourse prominence: Reconstruction in "focus" scrambling. In G. Legendre, J. Grimshaw \& S. Vikner (eds.), Optimality-Theoretic Syntax. Cambridge, Mass.: MIT Press, 143-169.

Chomsky, N. (1981). Lectures on government and binding. Dordrecht: Foris.

Cormack, A. \& N. Smith (2002). Compositionality, copy theory, and control. University College of London Working Papers in Linguistics 14, 355-373.

Cormack, A. \& N. Smith (2004). Backward control in Korean and Japanese. University College of London Working Papers in Linguistics 16, 57-83.

Fanselow, G. (2001). Features, $\theta$-roles, and free constituent order. Linguistic Inquiry 32, 405437.

Gamerschlag, T. (this volume). Semantic and structural aspects of complement control in Korean.

Hornstein, N. (2000). Move! A minimalist theory of construal. Oxford: Blackwell.

Hornstein, N. (2003). On control. In R Hendrick (ed.), Minimalist Syntax. Oxford: Blackwell, 6-81.

Hornstein, N. \& C. Boeckx (2004). Movement under control. Linguistic Inquiry 35, 431-452.

Jackendoff, R. \& P. Culicover (2003). The semantic basis of Control in English. Language 79, 517-556.

Johnston, J. \& I. Park (2001). Some problems with a lowering account of scrambling. Linguistic Inquiry 32, 727-732.

Kim, Y.-J. (2000). Subject/object drop in the acquisition of Korean: A cross-linguistic comparison. Journal of East Asian Linguistics 9, 325-351.

Kim, N.-K. (1978). Tolok sentential complements in Korean. In Papers in Korean Linguistics: Proceedings of the Symposium on Korean Linguistics. Columbia: Hornbeam Press, 137-147.

Kim, N.-K. (1984). The grammar of Korean complementation. Honolulu: Center for Korean Studies, University of Hawaii.

Ko, H. (2005). Syntactic edges and linearization. Ph.D. Diss., MIT.

Koster, J. (1984). On binding and control. Linguistic Inquiry 15. 417-459.

Kwon, N. \& M. Polinsky (2006). Object control in Korean: Structure and processing. JKL 15.

Kwon, N., M. Polinsky \& R. Kluender (2007). Processing of empty categories in Korean. MS.

Landau, I. (2003). Movement out of control. Linguistic Inquiry 34, 471-498.

Landau, I. (2004). The scale of finiteness and the calculus of control. Natural Language and Linguistic Theory 22, 811-877.

Landau, I. (2006). Severing the distribution of PRO from case. Syntax 9, 153-170.

Maling, J. \& S. Kim (1992). Case assignment in the inalienable possession construction in Korean. Journal of East Asian Linguistics 1, 37-68. 
Mazuka, R., K. Itoh \& T. Kondo (2002). Cost of scrambling in Japanese sentence processing. In M. Nakayama (ed.), Sentence processing in East Asian languages. Stanford: CSLI, 131-166.

Miyamoto, E. T. \& S. Takahashi (2002). Sources of difficulty in processing scrambling in Japanese. In M. Nakayama (ed.), Sentence processing in East Asian languages. Stanford: CSLI, 167-188.

Monahan, P. (2003). Backward object control in Korean. WCCFL 22, 356-369.

Monahan, P. (2005). Backward object control in Korean. Ms. University of Maryland.

Park, S-D. \& J. Whitman (2003). Direct movement passives in Korean and Japanese. In W. McClure (ed.) Japanese/Korean Lingustics 11. Stanford: CSLI, 307-321.

Polinsky, M. \& E. Potsdam (2002). Backward control. Linguistic Inquiry 33, 245-282.

Polinsky, M. \& E. Potsdam (2006). Expanding the scope of control and raising. Syntax 9, 171-192.

Potsdam, E. (2006). Backward object control in Malagasy: Against an empty category analysis. WCCFL 25, 328-336.

Saito, M. (2003). A derivational approach to the interpretation of scrambling chains. Lingua $113,481-515$.

Sells, P. (2005). Comments on object shift and cyclic linearization. Theoretical Linguistics 31, 185-198.

Sohn, H.-M. (2001). The Korean language. Cambridge Cambridge University Press

Tsoulas, G. (2004). On a binding-theoretic argument for base generation of long distance scrambling. York Papers in Linguistics, Series 2, 1, 223-236.

Ueno, M. \& R. Kluender (2003). Event-related brain indices of Japanese scrambling. Brain and Language 86, 243-271. 